\title{
INTRODUÇÃO À TEOLOGIA FUNDAMENTAL
}

\author{
Alex Sandro Nogueira Silva ${ }^{1}$ \\ LIBANIO, J.B. Introdução à teologia fundamental. São Paulo: Paulus, 2014.
}

Uma das grandes tarefas do teólogo é dialogar com a sociedade vigente, elaborando tal atividade consegue dar ao crente razões fundamentais para seu próprio crer. Isto se faz necessário frente a sociedade, a qual está em constante mudança, e nesse novo milênio, o sujeito contemporâneo vive ao entorno dos aspectos pautados pelas razões tecnocientíficas, cibercultura, consumismo e pelos dizeres dos detentores do discurso, gerando transformações socioculturais. Nesse contexto de mudanças no hodierno, a sociedade passa por um processo cada vez mais de urbanização e, com isso, dimensão religiosa sofre impactos, uma vez que a cultura atual nada contra o imaginário religioso. Eis o nascer da Teologia Fundamental, que se dirige ao mundo cultural e oferece ao homem moderno uma visão de fé tecnicamente elaborada.

Nesse contexto, dentro do aspecto religioso da Igreja Católica Apostólica Romana na América Latina, quais os desafios para a Teologia Fundamental - frente as condições socioculturais do mundo de hoje - que o cristão enfrenta para crer com clareza e integridade? Para responder a essa questão, o autor João Batista Libanio elaborou uma obra que é o resultado de uma formação para o fiel ou iniciante do curso de teologia, intitulada Introdução à Teologia Fundamental, publicado em 2014, que "lança primeiro olhar para a situação real e concreta. Descobre nela valências positivas e negativas que interferem na compreensão da fé. E sobre ela reflete à luz do grande projeto salvador de Deus” (LIBÂNIO, 20I4, p. 9).

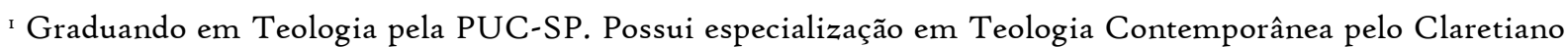
Centro Universitário (2019), graduação em Filosofia pela Faculdade Vicentina - Favi - Pr (2018) email: alexsandro.css@outlook.com
} 
O objetivo da obra consiste em apresentar ao estudante de teologia a dimensão da compreensão da fé elucidada, onde "teologia" trabalha a reflexão da fé e "fundamental" trata o interesse dos aspectos basilares da teologia. Para responder a tal objetivo, Libanio condessou o trabalho em sete fragmentos, que são: I) Situação cultural e religiosa atual, II) Percurso da Teologia Fundamental, III) Novos rumos da Teologia Fundamental, IV) A porta da fé, V) Ponto central: compreensão da revelação, VI) Escritura, Tradição e Magistério e VII) Revelação e nova evangelização.

O preâmbulo da obra nos situa em elementos fundamentais que provocaram as rápidas e profundas mudanças que ocorreram na sociedade. A mais notória mudança são as transformações no que diz respeito à cultura humana, e a mais visível e provocadora vem do campo da tecnologia e das comunicações. Esses aparatos caem em um amplo espaço, que se torna um campo perigoso, pois se declina a ideologia marcada por arma e controle, que apresenta uma ideia como fonte de defesa do ser humano contra o perigo. No entanto, segundo Libanio, "vale a metáfora da espada de dois gumes. Servem tais aparelhos microeletrônicos tanto para nos salvar de adversários como para eles nos atingirem. $\mathrm{O}$ mesmo míssil teleguiado, que defende uma nação, mata milhares de cidadãos de outra" (LIBANIO, 2014, p. 15). Sem falar das Fake News, sendo implantadas nos meios de comunicação, capazes de propagar mentiras, e o sujeito vai tomando para si e começa a utilizá-las no seu convívio social.

Um dos elementos construtivos da história são os mitos, que de certa forma impactam a sociedade em cada contexto. Os mitos que serão apresentados nesse momento são em si um conjunto de componentes que construiu o imaginário social do mundo moderno. Ao longo de alguns séculos, o continente Europeu transmitiu seu legado como a cultura dominante, capaz de tornar outros como suas classes subalternas. Isso se deu devido às várias conquistas, herdando a razão pelos gregos, o direito pelos romanos, do cristianismo a encarnação, dos judeus a palavras e por fim dos germanos o positivismo prático e o realismo. Assim, o mito europeu foi se solidificando, pois estes elementos anteriores ajudaram para que eles produzissem reflexões de altíssima qualidade, sem falar no campo 
das artes. Impôs que na Europa se encontrava a verdadeira fé. Apesar disso, não evitaram as guerras mundiais e o neonazismo que assola a humanidade até os tempos atuais. Fica o questionamento: como um continente que se considera o centro da intelectualidade pode agir ao longo de sua história com tantos preconceitos e crueldades? A resposta está no querer ter a supremacia do poder.

O mito do norte-americano se faz presente devido suas produtoras cinematográficas, com habilidades de construções fantasiosas e um tanto inimaginadas. Aqui cabe sua magnitude no campo propaganda, em ambos os casos produzem um grande poder dominador, ao ponto de controlar pessoas de países mais pobres. Com o auxílio do velho jargão “a propaganda é a alma do negócio” e com a ajuda do cinema, nos Estados Unidos se criou o mito de "como país onde se realizar o sonho da liberdade e como a terra de oportunidade, sobretudo para quem viva em regiões de opressão [...]” (LIBANIO, 20I4, p. 28). É uma liberdade tão falsa que há políticas imigratórias de difícil acesso, sem falar de vários indivíduos que morrem tentando entrar no país através do deserto para conquistar esse sonho, sem falar das ações que são tomadas para garantir a economia favorável aos seus interesses. Tanto o mito europeu como o norte-americano influenciaram e impactaram, de certo modo, todas as culturas. No Brasil, se criou o mito de dependência e de inferioridade deste, um país com tantas riquezas, potencialidades inexploradas e inesgotáveis, é considerado pobre. O mito brasileiro finca suas raízes ainda nas construções dos mitos estrangeiros.

A Teologia Fundamental tem a tarefa de pensar a fé de maneira crítica frente à nova cultura do hodierno, um mundo repleto de mudança. Ela trabalha basicamente a revelação como projeto salvífico no seio da sociedade, mostrando aos homens e mulheres sua dignidades de filhos de Deus. Já na antiguidade e na patrística, o cristianismo começou tentativas de defesa racional da fé cristã, que se deparava com a filosofia grega. Contudo, "ao longo da patrística, os padres construirão verdadeiras teologias fundamentais, ao expor, em confronto com posições diferentes e opostas, a verdade da fé cristã" (LIBANIO, 2014, p. 56). A Igreja medieval não tinha a necessidade de pensar em uma Teologia Fundamental, 
pois se acreditava que a única verdadeira religião vinha da Igreja Católica e tudo que não se encaixasse nesse sentido estava no erro. O trabalho dos primeiros padres se via em combater as heresias. Um pouco mais adiante, na Idade Moderna, a fé católica se depara com a Reforma Protestante, surgindo um novo tipo de apologética, que insistiu na objetividade das verdades dos ensinamentos doutrinais, usando do catecismo para normatizar a fé e sendo julgada como muito subjetiva no mundo protestante. Esse elemento vai de encontro com o mundo moderno, pois a subjetividade que ele propõe celebra a autonomia do sujeito. Com o caminhar da modernidade subjetiva e racionalista, levantaram-se novos problemas para a fé cristã. Para dar respostas, a teologia fundamental precede à teologia dogmática, ao lançar os seus fundamentos.

Diante das novas realidades latentes à Igreja, ela se propõe a novos rumos para se fazer uma Teologia Fundamental, pois antes do Concílio Vaticano II já havia uma série de movimentos que se mostraram importantes para a mudança de perspectiva da apologética tradicional. Segundo Libanio (2014, p. 73), “o novo movimento bíblico católico assumiu na interpretação da Escritura tanto a hermenêutica moderna como os avanços das ciências arqueológicas, históricas, literárias e outras investigações cientificas nas pegadas dos protestantes”. Assim, não se pode pensar em nenhuma Teologia Fundamental sem se pautar pelas pesquisas que geram outra atitude básica em face da Escritura e de seu uso na teologia. Desse modo, a nova Teologia Fundamental tem início após a Segunda Guerra Mundial, que passa a utilizar o método histórico-crítico, aqui se pede que ela esteja próxima da vida das pessoas, integrando a teologia e espiritualidade, para que juntas possam iluminar os cristãos na ação temporal.

A Teologia Fundamental elegeu elementos basilares em sua construção, pois precisa estar em contínuo processo de transformação, de novidade, para manter a teologia viva no seu conjunto. $\mathrm{O}$ novo ponto de partida se dá na realidade histórica da revelação, pois se cria o clima de se pensar a Teologia não mais pelos conceitos abstratos de revelação de Deus pela filosofia, mas no simples fato de percorrer a revelação ao longo da história. Se pensamos no itinerário Bíblico-histórico, a revelação inicia no Primeiro Testamento, no qual se tem os 
relatos da revelação de Deus, como intervenção livre e gratuita ao escolher o povo judeu para fazer aliança e manifestar-lhe o seu projeto salvífico. Já no Segundo Testamento, a revelação chega à plenitude ao manifestar a sua fonte trinitária. O Pai envia o Filho, ele realiza a palavra do Pai e envia o Espírito Santo para que os seguidores de Jesus até hoje anunciem tal mistério de salvação. Contudo, o Deus que primeiro se revelou aos profetas, em Jesus Cristo a Palavra se tornou o acontecimento máximo, pois Cristo é o Verbo, a Palavra encarnada, presente em nós, e nós como seus seguidores devemos continuar a anunciar o mistério salvífico.

Outro elemento básico que devemos levar em conta é o pobre, pois não se pode pensar em uma Teologia Fundamental, em um contexto de Igreja Latino-americana, sem explorarmos a Teologia da Libertação, pois "traz-lhe tal novidade. A opção pelos pobres fazse constitutiva da fé cristã. Não existe fé cristã sem opção pelos pobres” (LIBANIO, 20I4, p. 84). O sentido aqui não cai em um pensamento contra adversários conservadores, mas na própria opção que Deus Pai fez pelo pobre, representada na historiografia do Primeiro Testamento. E essa opção continua em Jesus Cristo no Segundo Testamento; Bento XVI nos afirma que a opção pelos pobres é implicada pela ação de um Deus que se faz pobre para nos enriquecer. Maria de Nazaré torna-se uma figura indispensável na elaboração de uma Teologia Fundamental, pois faz parte da tradição eclesial católica. No aspecto bíblico, Maria mostra-nos a figura de uma mulher que vivia de fé, que se esforçava para compreender o significado dos atos de Jesus. A Teologia Fundamental nos ajuda a não distorcemos a figura de Maria, e nos permite elaborar o verdadeiro papel que ela tem no contexto do catolicismo, sem ternos que cair em uma glorificação mítica sobre ela.

O Papa Bento XVI, na Carta Porta Fidei (2012), oferece excelente metáfora para a Teologia Fundamental. O objetivo dessa carta é estudar as portas de saída que a sociedade social abre e as de entrada que a Igreja oferece. As portas são uma linguagem figurativa, mas demonstra de forma figurativa as posturas da Igreja frente aos questionamentos que a sociedade se coloca a fazer. Um ponto de grande importância que se coloca de início são as portas de saída da fé católica, um dos primeiros embates se pode dizer que está no campo da 
ciência, pois a fé cristã nos últimos séculos teve caráter tridentino de reação à Reforma Protestante.

$\mathrm{Na}$ medida em que os fiéis tomam posições e começam a se familiarizar com a ciência, sobretudo na leitura da criação, inicia-se um embate entre fé e ciência, pois uma mostra-se contrária da outra. E isso vai ganhando mais visibilidade a partir da autonomia do sujeito, que seria outra porta de saída. Neste fato, se pensamos a fé que era transmitida segundo os costumes e tradições familiares, hoje está, já não é tão influente devido a juventude se atirar no campo da racionalidade das universidades, na ciência e tecnologia. Assim, cresce a consciência dá própria autonomia e percebe, que o sujeito escolhe sua autonomia subjetiva, a qual lhe possibilita pensar e agir à sua maneira. Poderíamos elencar várias portas de saída, mas o que é visível é o modo como o sujeito vai aderindo em si a cultura moderna. E a fé cristã não encontrou somente portas de saída, caso contrário a história das religiões já teria se findado.

A porta de Deus, respeitando a liberdade das criaturas, torna-se uma porta de entrada da fé católica, porém a iniciativa para abri-la parte de Deus "nenhuma porta se nos franquearia se Deus não estivesse lá primeiro" (LIBANIO, 2014, p. 125). A porta de entrada se fundamenta no próprio ato criativo da Trindade, pois ao fazer-nos existir ela nos chama para a comunhão, nisso está a origem de toda fé. Deus nos chama a seu amor, e as respostas a isto estão na liberdade que nos seres humanos temos de responder ao sim ao não. $\mathrm{O}$ agir de Deus está na história, ao interpretar as palavras e ações dele.

Uma porta significativa é a da comunidade, que aponta a realidade para a qual a fé cristã se abre, e isto se concretiza em dois sacramentos fundamentais da vida cristã: Batismo e Eucaristia. Nesse sentido, “o papa referiu-se à comunidade pela perspectiva ontológica do batismo e da eucaristia. Pela força dos sacramentos, constitui-se a comunidade" (LIBANIO, 2014, p. 131). Uma outra porta que faz comunhão a esses dois elementos é a porta da beleza da liturgia, pois após o Vaticano II, no seio da comunidade a liturgia com sua beleza adere a participação dos fiéis, dando um novo significado as celebrações. Há outros elementos que 
atraem as pessoas para entrar, são essas duas grandes portas que nos abrem para a vida de fé.

O ponto central para a compreensão da revelação se dá no conceito do Antigo e Novo Testamento. A Teologia Fundamental compreende a revelação no Antigo Testamento como o projeto salvífico e, no Novo Testamento, a plenitude. Nesse sentido, é preciso um estudo aprofundado do conceito de revelação, bem como o itinerário histórico onde ela ganha novos sentidos. Vamos perpassar os Concílios Vaticano I e Vaticano II para compreensão da evolução da revelação. O Concílio Vaticano I se encontrava no auge da explosão da cultura da modernidade, a Igreja sofria com o anticlericalismo, críticas radicais à fé. Esse concílio assegura dois elementos fundamentais para a compreensão da revelação: o primeiro está relacionado à liberdade e à gratuidade de Deus de revelar-se ao homem, e o segundo garante, a capacidade da inteligência humana por ela mesma de chegar à verdade sobre a existência de Deus. O concílio deseja salvaguardar os fundamentos da possibilidade da revelação de Deus "contra uma razão por demais pretensiosa e contra uma visão pessimista da razão humana" (LIBÂNIO, 20I4, p. I66).

A revelação no Concílio Vaticano II é constituída pela constituição dogmática Dei Verbum, sendo um avanço da constituição dogmática Dei Filius, do Concílio Vaticano I, sendo focada a dimensão trinitária da revelação. Libanio (2014), aponta que "Deus Pai revelase a $\mathrm{Si}$ mesmo e torna conhecido o mistério de sua vontade. O Filho permite aos homens acesso ao Pai no Espírito Santo. Eles se tornam participantes da natureza divina" (p. I67). Esse concílio entende o ser humano numa abertura existencial para Deus e pelo mesmo ato criativo ele é chamado a viver em comunhão de amor com Ele. Assim se estrutura a revelação bem diferente da apologética clássica, pois se oferece o núcleo para interpretar a revelação para dentro da cultura atual. Acentuando a dimensão trinitária da revelação de Deus, "a participação da natureza divina, o grande amor do Deus invisível a conversar conosco como amigos, o convite à comunhão, a mútua relação dos atos e das palavras, das obras e dos ensinamentos" (LIBANIO, 2014, p. I68). 
A Teologia Fundamental católica enfrenta desafios em relação aos temas da revelação entre Escritura, Tradição e Magistério. Tudo parte de ponto comum, ou seja, Deus se autocomunica salvificamente com os seres humanos. Ao passar pelo campo da Escritura e da Tradição, vemos que ambas se entrelaçam, pois a Escritura como Oráculo de YHWH garante a verdade de tudo o que nela se escreveu, sendo ela o alimento da fé da Igreja. Já a Tradição cumpre a função de mostrar como a Escritura vai sendo interpretada ao longo da Tradição de fé da Igreja, pode-se entendê-la como uma perspectiva do Espírito que não descarta a letra, mas lhe dá vida. Os dogmas e o Magistério são de íntima conexão com a Tradição, pois com eles a Igreja não se estende apenas como o depósito da fé, mas como transmissora fiel.

Por fim, a nova evangelização, que se baseia em como anunciar a fé ao mundo de hoje, nasce em um contexto de Igreja Latino-Americana, cujo pensamento religioso pensa e dialoga com a evangelização a partir dos pobres, das culturas nativas e populares, na linha de sua libertação. A ação da nova evangelização trata de um processo libertador da pessoa humana, possibilitando à sociedade uma ruptura do sistema dominante, favorecendo a vida religiosa inserida e a educação libertadora. Assim se propõe, à luz da fé, anunciar e realizar a libertação, caminhando na linha da enculturação da fé cristã, pensando a comunidade como lugar e fonte de evangelizadora.

A obra se torna oportuna em sua conjuntura bem-organizada e de fácil compreensão, além de trazer elementos que dialogam com a sociedade vigente e que foram consolidando a sua história. Assim, ela auxilia professores, estudantes de graduação em Teologia e áreas afins e pesquisadores; até mesmo proporciona ao fiel católico um contato com a Teologia Fundamental como disciplina e prática que estuda a sociedade e ampara o teólogo em dar razões da fé ao ser humano. E dessa forma ela assume a missão de elucidar os católicos no referente à própria fé em meio à cultura altamente fragmentada e instável, em um contexto de constante mudança.

Cabe também ressaltar que a obra em cada final de capítulo apresenta propostas de dinâmicas de grupo, as quais possibilita uma aplicação tanto na área pastoral como no âmbito 
da academia. O autor se baseia em vários autores e documentos do magistério eclesiástico para responder a suas próprias indagações, proporcionando pesquisas futuras. A conclusão que ele oferece apresenta que a teologia fundamental não deve se estacionar, mas o seu programa condiz em dizer às mentes e corações o projeto salvífico de Deus, com encanto, deslumbramento, fascinação e admiração. E na atual conjuntura, na qual a humanidade é assolada pela Covid-ı9, vê-se novamente um importantíssimo trabalho da Teologia Fundamental, que diante a essa e outras crises, possibilita ao ser humano um olhar de esperança. 